\title{
Identification of Dermatophyte Fungi Causing Tinea pedis and Tinea unguium in Malabero Coastal Communities, Bengkulu
}

\author{
MARDHATILLAH SARIYANTI ${ }^{1 *}$ PUTRI MAYA AGUSTRIA ${ }^{2}$, WILLUJENG FANNY \\ HERLAMBANG $^{2}$, BESLY SINUHAJI ${ }^{1,3}$, RISKY HADI WIBOWO ${ }^{4}$, NOVRIANTIKA LESTARI ${ }^{1}$, \\ ENNY NUGRAHENI ${ }^{1}$, AND SIPRIYADI ${ }^{4}$
}

${ }^{1}$ Faculty of Medicine and Health Sciences, University of Bengkulu, Indonesia;

${ }^{2}$ Medical Study Program, Faculty of Medicine and Health Sciences,

University of Bengkulu, Indonesia;

${ }^{3}$ Clinical Laboratory of RSKJ Soeprapto Bengkulu, Indonesia;

${ }^{4}$ Departmen of Biology, Faculty of Mathematic and Natural Science,

University of Bengkulu, Indonesia.

\begin{abstract}
Dermatophytosis cases have increased significantly in various countries, more than $20-25 \%$ of the population were infected by superficial fungal infections. Malabero urban village is a coastal area in Bengkulu city with high temperature and humidity. The daily activities of residents in the area are mostly fishermen, so they are in a watery or wet environment for approximately 12 hours every day. Hence, this research aimed to identify dermatophyte fungi that caused Tinea pedis and Tinea unguium from these coastal communities. The diagnosis of Tinea was based on symptoms and physical examination of the lesion area. Furthermore, specimen collection was carried out by scraping the lesion area, then examined with $20 \% \mathrm{KOH}$ and fungal culture on sabouraud dextrose agar media. Subjects included 79 people who had symptoms of Tinea pedis and 33 people with symptoms of Tinea unguium. The results of dermatophyte fungi identification were obtained, namely Trichophyton mentagrophytes, Trichophyton rubrum, Trichophyton tonsurans, and Aspergillus niger. Our conclusion is the most identified dermatophyte species is Trichophyton mentagrophytes.
\end{abstract}

Key words: coastal, dermatophyte, Tinea pedis, Tinea unguium

Kasus dermatofitosis meningkat signifikan di berbagai negara, lebih dari 20-25\% populasi terinfeksi oleh jamur superfisial. Kelurahan Malabero merupakan salah satu kawasan pesisir di Kota Bengkulu dengan temperatur tinggi dan lembab. Aktivitas sehari-hari penduduk di kawasan tersebut sebagian besar adalah nelayan, sehingga berada di lingkungan yang berair atau basah kurang lebih 12 jam setiap hari. Oleh karena itu, penelitian ini bertujuan untuk mengidentifikasi jamur dermatofita penyebab Tinea pedis dan Tinea unguium pada masyarakat pesisir tersebut. Diagnosis Tinea didasarkan pada gejala dan pemeriksaan fisik pada area lesi. Selanjutnya pengambilan spesimen dilakukan dengan pengerokan daerah lesi, kemudian diperiksa dengan $\mathrm{KOH}$ 20\% dan kultur jamur pada media Sabouraud Dextrose Agar (SDA). Subjek penelitian meliputi 79 orang yang memiliki gejala Tinea pedis dan 33 orang dengan gejala Tinea unguium. Hasil identifikasi jamur dermatofita diperoleh Trichophyton mentagrophytes, Trichophyton rubrum, Trichophyton tonsurans, dan Aspergillus niger. Kesimpulan penelitian ini adalah spesies dermatofita yang paling banyak teridentifikasi adalah Trichophyton mentagrophytes.

Kata kunci: dermatofit, pesisir, Tinea pedis, Tinea unguium

Fungal disease kill more than 1.5 million and affect over a billion people, so it become a serious public health problem '-(Bongomin et al. 2017). The current report from 14 countries, $12.5 \%$ of the global population were affected by fungal disease (Denning 2017). Dermatophytosis is the most common infectious disease in the world, especially in developing countries, caused by dermatophyte fungi. The incidence of dermatophytosis is more than $20-25 \%$ of the population worldwide (Havlickova, Czaika and Friedrich 2008). A

*Corresponding author: Phone: +62-85-664924312; Fax: +62-; E-mail: mardhatillahs@unib.ac.id cross-sectional study has been conducted by 'Araya, Tesfaye and Fente (2020), showed that the prevalence of dermatophytosis was $46.5 \%$, but in developed countries, it was less than $5 \%$ which indicates that dermatophytosis is still a common problem in developing countries. Tinea pedis infects about $10 \%$ of the world's population, whereas the prevalence of Tinea unguium in Asia reaches 12.1\% (Behzadi, Behzadi and Ranjbar 2014; Sigurgeirsson and Baran 2014). The distribution of causative species vary with geographic region, such as Trichophyton rubrum, $T$. mentagrophytes, Microsporum canis, and Epidermophyton floccosum(Ameen 2010). 
Dermatophytosis has emerged as a social, psychological, and economic burden on the society regarding its chronic and recurrent course (Patro, Panda and Jena 2019). The Tinea infections are common in tropics with higher humidity geographical areas, overpopulation, and poor hygienic living conditions (Weitzman and Summerbell 1995). Tropical climate and higher humidity conditions are good environment for the growth of dermatophyte fungi. Personal hygiene is important because good personal hygiene will minimize the entrance (port de entry) of microorganisms into the body, so it can prevent someone from contracting the disease (Richardson and Edward 2000).

Coastal areas are often associated with health problems because coastal communities generally pay little attention to environmental cleanliness, thus impacting the quality of public health in the coastal environment (Fleming et al. 2006; Stewart et al. 2008). High humidity in the coastal area is a factor that strongly supports the growth and development of pathogens, such as fungi. Some aspects of health that are a problem in coastal areas are environmental health, infant and toddler health, and maternal health (Heller, Colosimo and De Figueiredo Antunes 2003).

Indonesia is an archipelago region, located in the equator, and have a tropical climate. These condition allow to develop infectious diseases, such as fungal infection. Based on geographical location, Bengkulu province has a wet tropical or type A tropical climate (rain tropical) with humidity of 81 to $91 \%$, the maximun temperature average of $29-30^{\circ} \mathrm{C}$, and minimum temperature of $23-24^{\circ} \mathrm{C}$ every month. Malabero village is one of the coastal areas in the city of Bengkulu with total population about 2,486 residents. The most of community working as fishermen and other activities are doing traditional fish processing (Hayati and Handayani 2014). Therefore, it was the first research to identify the occurrence of Tinea pedis and Tinea unguium in Malabero residents, and also using macroscopic and microscopic examination trough $\mathrm{KOH}$ and SDA culture to identify the species of dermatophyte causing both of Tinea.

\section{MATERIALS AND METHODS}

Subject Selection. The research was a cross sectional design study with population of the residents of Malabero village which has the symptoms of Tinea pedis and Tinea unguium from physical examination. In the first stage, research subjects were selected based on inclusion and exclusion criteria. Inclusion criteria included, Malabero coastal communities who had symptoms of Tinea pedis and Tinea unguium, and were over 18 years old. Exclusion criteria included, Malabero coastal communities suffering from chronic diseases, such as tuberculosis, diabetes mellitus and cushing disease; use steroids for a long time (more than 2-4 weeks of administration); and experiencing immunological function disorders, such as the Acquired Immuno Deficiency Syndrome (AIDS). Furthermore, the subjects were geft an explanation and inform concent sheet.

Macroscopic and Microscopic Identification of Dermatophye Fungi. Identification of dermatophyte fungi was carried out at the Microbiology Laboratory, Department of Biology, Faculty of Mathematics and Natural Sciences, University of Bengkulu. The skin and nail lesions of subject were cleaned with $70 \%$ ethyl alcohol using sterile cotton. Research sample of scraping the lesion, then transferred to the laboratory as soon as possible for direct microscopic examination and culturing. Sample for Tinea pedis suspect took from the fourth toe clefts of both feet, while in Tinea unguium was sampled by scraping material from the white spots on the surface of the nail. Microscopic examination of specimens was performed following treatment with an aqueous solution of $20 \%$ potasium hydroxide $(\mathrm{KOH})$, then all samples were cultured on Saboroud Dextrose Agar (SDA) medium. Identification of fungal characters included macroscopic and microscopic examination.

\section{RESULTS}

The total of research subjects included 106 people who had symptoms of Tinea pedis or Tinea unguium in Malabero coastal community. The most age group and gender characteristics of subjects with Tinea pedis and Tinea ungium symptoms were adult age group (26-45 years) and female group (Table 1). The distribution of each Tinea pedis and Tinea unguium cases based on age groups classification were 35 cases accounting for $46.8 \%$ and 21 cases accounting for $55.7 \%$. Whereas, 41 females with Tinea pedis representing $56,2 \%$ of total cases and 20 females representing $60.6 \%$ of the total Tinea unguium cases.

Dermatophyte species identification that cause of Tinea pedis and Tinea unguium was carried out through macroscopic and microscopic examination. From all specimens, four species of dermatophytes were identified, which T. mentagrophytes were the most 
Table 1 Data of patients suffering dermatophytosis in coastal communities, Malabero Village according to age group

\begin{tabular}{|c|c|c|c|c|c|c|}
\hline \multirow[t]{2}{*}{ Clinical type of Tinea } & \multirow[t]{2}{*}{ Gender } & \multicolumn{3}{|c|}{ Age groups (yr) } & \multirow{2}{*}{$\begin{array}{c}\text { Total } \\
\text { male/female }\end{array}$} & \multirow[t]{2}{*}{ Total } \\
\hline & & $18-25$ & $26-45$ & $46-65$ & & \\
\hline \multirow[t]{2}{*}{ Tinae pedis } & Male & 2 & 14 & 16 & 32 & 73 \\
\hline & Female & 5 & 21 & 15 & 41 & \\
\hline \multirow[t]{2}{*}{ Tinea unguium } & Male & 1 & 6 & 6 & 13 & 33 \\
\hline & Female & 1 & 10 & 9 & 20 & \\
\hline Total & & 9 & 51 & 46 & $45 / 61$ & 106 \\
\hline
\end{tabular}

Table 2 Distribution of dermatophyte causing Tinea pedis and Tinea unguium

\begin{tabular}{cccc}
\hline \multirow{2}{*}{ Fungal species } & & \multicolumn{2}{c}{ Number of case in type of Tinea } \\
& Tinea pedis & Tinea unguium \\
\hline \multirow{2}{*}{ Trichophyton rubrum } & Male & 10 & 4 \\
& Female & 10 & 6 \\
Trichophyton mentagrophytes & Male & 21 & 7 \\
& Female & 25 & 11 \\
Trichophyton tonsurans & Male & - & 1 \\
& Female & 2 & 1 \\
& Male & 1 & 2 \\
& Female & 4 & 33 \\
\hline
\end{tabular}

commnon, followed by T. rubrum, and T. tonsurans. Trough $\mathrm{KOH}$ and culture examination of specimens, $T$. mentagrophytes was the most etiological agent of 46 Tinea pedis cases accounting for $63 \%$ of total cases, and was identified in 18 Tinea unguium cases representing $54,4 \%$ of total cases. T. rubrum was ranked the second most frequent dermatophyte fungi causative agent being identified in 20 cases of Tinea pedis and 10 cases of Tinea unguium, followed by $T$. tonsurans was responsible for 2 cases each of Tinea pedis and Tinea unguium. Filamentous nondermatophytes including Aspergillus niger was rare as causative agents of $6,8 \%$ and $9,1 \%$ cases each of Tinea pedis and Tinea unguium total cases (Table 2).

In figure 1 showed the macroscopic morphology of the dermatophye and non-dermatophye species had been indentified. Macromorphological examination of T. mentagrophytes on SDA medium showed varied of colonies colour from white to cream or yellowish with a powdery to granular surface like a pile of cotton and no pigment appears on the surface of the reverse colony. T. rubrum species exhibited downy to cottony in texture with white coloured on the surface and brownish yellow pigmentation on the reverse colonies.
The macroscopic morphology of $T$. tonsurans had a yellowish white surface with velvety or powdery texture and feathers at the edges surface. While, Aspergillus niger morphologically identified was characterized by yellowish green to olive green colonies and with uniform black to greyish black colonies on the reverse colonies.

Microscopic examination of $T$. mentagrophytes showed septate hyphae which branced conidiophores extend, numerous single-celled microconidia, often in dense clusters like grapes. Macroconidia were cigar to club shaped and may exhibit some distortion. While microscopic morphology of $T$. rubrum exhibited hyaline septate hyphae, characterized by several tearsshaped microconidia, and macroconidia formed directly on the ends of thick hyphae singly or in groups. Microscopic morphology of $T$. tonsurans produced septate hyphae and the most prominent feature was the numerous microconidia formed along the hyphae. The microconidia were pyriform (tear-drop) to clavate (club-like) to cylindrical shaped, while cacroconidia were rare and also showed from cylindrical to cigar shaped. Whereas microscopic examination of Aspergillus niger featured a large number of conidia on 

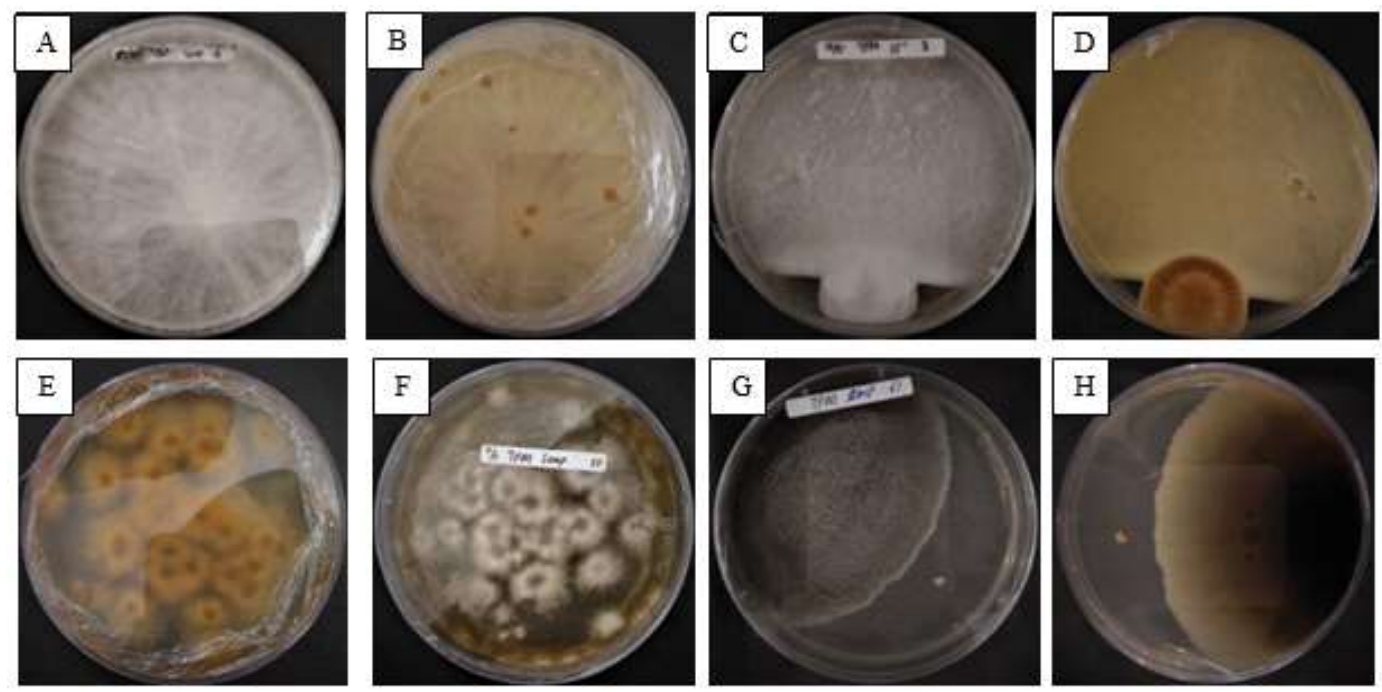

Fig 1 Macroscopic morphology of fungal species, A,B: surface \& reverse T. mentagrophytes, C,D: surface \& reverse T. rubrum, E,F: surface \& reverse T. tonsurans, G,H: surface \& reverse Aspergillus niger.
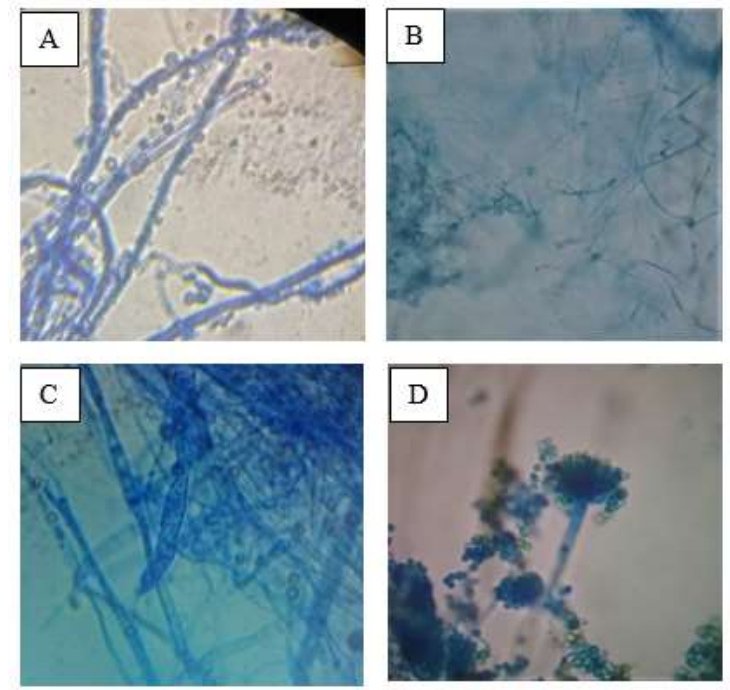

Fig 2. Microscopic examination of fungal species, A: T. mentagrophytes, B: T. rubrum, C: T. tonsurans, D: Aspergillus niger.

vesicles (Figure 2).

\section{DISCUSSION}

The sex of the study subjects who experienced Tinea pedis and Tinea unguium were mostly women with a total of 61 people $(57.5 \%)$. This condition caused by the activity of the most women in the Malabero village have been doing traditional fish processing. Many factors that support skin infections of the community in the area are personal hygiene, a moist and wet environment, and heavy sweating (Hayati and Handayani 2014). A person who is active in a hot and humid work environment will more often sweat and make the body in humid conditions. These conditions can increase risk factors for fungal infections. According Havlickova, Czaika and Friedrich (2008), the distribution of dermatophytes varies with geographical region and with a wide range of environmental and socio-economic conditions, as well as cultural factors.

Differences on the global public health problems also reflect the different of community and environmental hygiene, as well as different availability of therapeutic measures. The low education level of this research subjects was one of the factors that influence poor personal hygiene in Malabero coasta community. According to Pascapurnama et al. (2018), good education about the importance of foot hygiene, can help prevent and minimize the progression of Tinea 
pedis. Study by 'Olutoyin, Onayemi and Gabriel, (2017) was identified certain factors as being significant for the development of superficial fungal infections, included behavioral characteristics such as poor hygienic habits.

Most of the research subjects were in the advanced adulthood group, at the 26-45 years and 46-65 years age groups with a total of 97 people (91.5\%). In the study of -Hidayati et al. (2009), at the regional general hospital, Dr. Soetomo Surabaya in 2003-2005, also found the most age groups suffering from dermatophytosis at the age of 25-44 years (36.3\%). According to Adams et al. (2015), that age group was classified as productive age or working age, so that activities that produce sweat in high intensity with poor personal hygiene, thus causing an increased risk of dermatophytosis. In another study conducted by -Bertus et al. (2015), in Pertamina General Hospital, Prof. Dr. Kandou Manado, the age group of 45-64 years (49.24\%) were the most patient who were infected with dermatophytosis. It was thought to be caused by immune system decreasing trough the increased of age. Fungal diseases can attack all age levels, but in people with immunocompromised, they are more susceptible to fungal infections. With increasing age, it also increases the risk of degenerative diseases, which are also predisposing factors for fungal infections (Gow and Netea 2016).

According to a cross sectional study conducted on patients who attended the Dermatology outpatient department, showed nail specimens positive by culture, Trichophyton mentagrophytes was the major isolate followed by Trichophyton tonsurans and Trichophyton rubrum (Balamuruganvelu, Reddy and Babu 2019), while the study by -Gupta et al. (2018), highlighted a rise in dermatophyte infection caused $T$. verrucosum which is a zoophilic dermatophyte. The most sequential transmission of dermatophytosis to humans is zoophilic, anthropic and geophilic(Brown et al. 2012). The condition of Malabero village which is densely populated, so it is very possible for dermatophyte transmission. The results obtained were in line with research conducted-Hidayati et al. (2009), dermatophytosis caused by T. mentagrophytes had the highest percentage of $15.7 \%$, followed by $T$. rubrum with a percentage of $13.7 \%$.

Aspergillus niger was identified to cause Tinea pedis by $6.3 \%$. The fungus species is often found in soil, water and decaying vegetation. Because these species are often found in the soil, if walking barefoot or not cleaning the feet properly can cause infection of this species. Aspergillus niger usually attacks immunocompromised patients, but can also attack immunocompetent patients. And also able to metabolize the keratin layer, but with lower efficiency than dermatophytes, this makes this genus can cause Tinea pedis (Viegas et al. 2013). Tinea pedis lesions caused by $A$. niger are similar to lesions caused by dermatophytes, called pseudodermatophytes. Hot and humid environmental conditions in the Malabero village can increase Tinea pedis infection caused by this fungus species. According to Tosti, Piraccini and Lorenzi (2000), Tinea pedis caused by A. niger occurs more in the tropics and subtropics with hot and humid climates, such conditions are endemic areas of $A$. niger.

\section{ACKNOWLEDGEMENTS}

We would like to acknowledge the support from Medical Study Program, Faculty of Medicine and Health Sciences University of Bengkulu. The authors are also deeply grateful for all participants of Malabero Coastal Community and laboratory technicians of Basic Science Laboratory, Faculty of Mathematic and Natural Sciences University of Bengkulu.

\section{REFERENCES}

Adams, C. et al. 2015. Environmental and Genetic Factors on the Development of Onychomycosis. Journal of Fungi. 1(2): 211216. doi: 10.3390/jof1020211.

Ameen, M. 2010. Epidemiology of superficial fungal infections. Clinics in Dermatology. 197201. doi: 10.1016/j.clindermatol.2009.12.005.

Araya, S., Tesfaye, B. and Fente, D. 2020. Epidemiology of dermatophyte and non-dermatophyte fungi infection in Ethiopia. Clinical, Cosmetic and Investigational D e r m a to logy. 13: 291297 . do i : 10.2147/CCID.S246183.

Balamuruganvelu, S., Reddy, S. V and Babu, G. 2019). Age and Genderwise Seasonal Distribution of Dermatophytosis in a Tertiary Care Hospital, Puducherry, India. Journal of Clinical and Diagnostic Research. 13(2). doi: 10.7860/jcdr/2019/39515.12615.

Behzadi, P., Behzadi, E. and Ranjbar, R. 2014. Dermatophyte fungi: infections, diagnosis and treatment. SMU Medical Journal. 5062.Bertus, N. V. P. et al. 2015. Profil dermatofitosis di poliklinik kulit dan kelamin rsup prof. dr. r. d. kandou manado periode JanuariDesember 2012. Jurnal e-Clinic (eCl). Available at: https://ejournal.unsrat.ac.id/index.php/ eclinic/article/view/8862 (Accessed: 27 March 2020).

Bongomin, F. et al. 2017. Global and multi-national 
prevalence of fungal diseases-estimate precision. Journal of Fungi. 3(4). doi: 10.3390/jof3040057.

Brown, G. D. et al. 2012. Hidden killers: Human fungal infections. Science Translational Medicine. American Association for the Advancement of Science. 165rv13165rv13. doi: 10.1126/scitranslmed.3004404.

Denning, D. W. 2017. Calling upon all public health mycologists: To accompany the country burden papers from 14 countries. European Journal of Clinical Microbiology and Infectious Diseases. 36(6): 923924. doi: 10.1007/s10096-017-2909-8.

Fleming, L. E. et al. 2006. Oceans and human health: Emerging public health risks $\mathrm{n}$ the marine environment. Marine Pollution Bulletin. 53(1012): 545560. doi: 10.1016/j.marpolbul.2006.08.012.

Gow, N. A. R. and Netea, M. G. 2016. Medical mycology and fungal immunology: New research perspectives addressing a major world health challenge. Philosophical Transactions of the Royal Society B: Biological Sciences. $371(1709)$. doi: 10.1098/rstb.2015.0462.

Gupta, A. K. et al. 2018. Studying the clinic mycological pattern of the dermatophytic infection attending OPD in tertiary care hospital in eastern Uttar Pradesh and Bihar. International Journal of Research in Dermatology. 4(2): 118125. doi: 10.18203/issn.24554529.intjresdermatol20180987.

Havlickova, B., Czaika, V. A. and Friedrich, M. 2008. Epidemiological trends in skin mycoses worldwide. Mycoses.215. doi: $10.1111 / \mathrm{j} .1439$ 0507.2008.01606.x.

Hayati, I. and Handayani, Z. P. 2014. Identifikasi jamur malassezia furfur pada nelayan penderita penyakit kulit di rt 09 kelurahan malabro kota bengkulu. GRADIEN: Jurnal Ilmiah MIPA. Available at: https://ejournal.unib.ac.id/index.php/gradien/article/vi ew/135 (Accessed: 27 March 2020).

Heller, L., Colosimo, E. A. and De Figueiredo Antunes, C. M. 2003. Environmental sanitation conditions and health impact: A case-control study. Revista da Sociedade Brasileira de Medicina Tropical. 36(1): 4150. doi: 10.1590/S0037-86822003000100007.

Hidayati, A. N. et al. 2009. Mikosis Superfisialis di Divisi Mikologi Unit Rawat Jalan Penyakit Kulit dan Kelamin RSUD Dr . Soetomo Surabaya Tahun 20032005
(Superficial Mycosis in Mycology Division - Out Patient Clinic of Dermatovenereology Dr . Soetomo General Hospital Surabaya. Berkala Ilmu Kesehatan Kulit dan Kelamin. 21: 18.

Olutoyin, O. O., Onayemi, O. and Gabriel, A. O. 2017. Risk factors associated with acquiring superficial fungal infections in school children in South Western Nigeria: A comparative study, African Health Sciences. 17(2): 330336. doi: 10.4314/ahs.v17i2.6.

Pascapurnama, D. N. et al. 2018. Integrated health education in disaster risk reduction: Lesson learned from disease outbreak following natural disasters in Indonesia. International Journal of Disaster Risk Reduction. 94102. doi: 10.1016/j.ijdrr.2017.07.013.

Patro, N., Panda, M. and Jena, A. 2019. The menace of superficial dermatophytosis on the quality of life of patients attending referral hospital in Eastern India: A cross-sectional observational study. Indian Dermatology Online Journal, 262. doi: 10.4103/idoj.idoj_342_18.

Richardson, M. and Edward, M. 2000. Model systems for the study of dermatophyte and non-dermatophyte invasion of human keratin. Biology of dermatophytes and other keratinophilic fungi. 11521.

Sigurgeirsson, B. and Baran, R. 2014. The prevalence of onychomycosis in the global population A literature study. Journal of the European Academy of Dermatology and Venereology. 28(11): 148091. doi: $10.1111 /$ jdv. 12323 .

Stewart, J. R. et al. 2008. The coastal environment and human health: Microbial indicators, pathogens, sentinels and reservoirs in. Environmental Health: A Global Access Science Source. doi: 10.1186/1476069X-7-S2-S3.

Tosti, A., Piraccini, B. M. and Lorenzi, S. 2000. Onychomycosis caused by nondermatophytic molds: Clinical features and response to treatment of 59 cases. Journal of the American Academy of Dermatology. 42(2I): 217224. doi: 10.1016/S0190-9622(00)90129-4.

Viegas, C. et al. 2013. Diagnosis of Tinea pedis and onychomycosis in patients from Portuguese National Institute of Health: 3641.

Weitzman, I. and Summerbell, R. C. 1995. The dermatophytes, clinical microbiology reviews. Available at: http://cmr.asm.org/ 